日本水処理生物学会誌

Jap. J. Water Treat. Biol., Vol.26, No.1, 1990

\title{
羽状ケイ藻Cymbella lata Grun.の分類学的検討 (1) Taxonomical Studies on Pennate Diatom Cymbella lata Grun. (1)
}

\author{
福島 博 ${ }^{1)}$. 小林艶子 $\left.{ }^{2}\right) \cdot$ 鈴木康人 ${ }^{3)} \cdot$ 大塚晴江 $\left.^{4}\right)$ \\ (東京女子体育大学 ${ }^{1}$ ) - 横浜市立大学 ${ }^{2}$ ，3) - 神奈川県薬剂師会公害衛生試験所 ${ }^{4}$ ) )
}

\begin{abstract}
Hiroshi FUKUSHIMA ${ }^{1)}$ - Tsuyako KO-BAYASHI ${ }^{2}$ - Yasuto SUZUKI ${ }^{3)} \cdot$ Harue OHTSUKA $^{4)}$
(Tokyo Women's College of Physical Education'), Yokohama City University ${ }^{2}{ }^{1}, 3$ ), Environmental Analysis Institute of Kanagawa Association $\left.{ }^{4}\right)$ )
\end{abstract}

\section{1.はじめに}

志賀高原東館山の山頂に近い小さい水溜りで1989年7 月にえた試料に本種が多量に生育していたので，433個 体を演者らの定法に従って研究した結果を報告する。本 種の報告は多くなく，生育環境も充分解明されていない。 本種は背腹性の弱いCymbellaの1種で後に記すように形 態変異のかなり大きい種である。

\section{2. ケイ殼の外部形態}

ケイ殼の外形は背腹性の弱い幅広い帶披針形で，瀬側 の湾出はやや強いが, 腹側の湾出は弱い(Plate 1 Figs $\mathrm{E} \sim \mathrm{H})$ 。このような形態は $36.2 \%$ あ゙あ。腹縁の中央 部がほほ真直になる個体 (Plate 1 Figs A D ) が多く $63.8 \%$ に達している。ケイ殸の両端部は殆んど突出しな いものと，僅かに突出するものがあるが，どちらとも区 別の困難なものが多い。軸域はやや狭い。(Plate 2 Figs $\mathrm{A} \sim \mathrm{D})$ 個体もあるが，個体数は少なく(11.3\%)，中位 から幅広い個体(Plate 2 Figs E H H)が多い(88.7\%)。 中心域は棈円状で，大きくないものがあるが(Plate 3 Figs $\mathrm{A} \sim \mathrm{D})$, このものは少なく $(16.9 \%)$, 大きいもの が(Plate 3 Figs E〜H) 多い $(83.1 \%)$ 。中心域の
大きさは背腹がほほ同じもの(Plate 4 Figs A〜D)が 多く67.4\%である。背側が腹側より大きいもの (Plate 4 Figs $\mathrm{E} \sim \mathrm{H})$ は多くなく20.9\%で，背側が腹側より小 さいものはさらに少なく $11.7 \%$ を占めるにすぎない。

Voigt-Diskordanzが背側上に1つある(Plate 5 Figs E〜H)のは4.7\%で，背側下に1つある(Plate 6 Figs A Ｄ)のも少なく $3.8 \%$ である。腹側上に1つある (Plate 6 Figs $E \sim G)$ の $3.1 \%$ ある。背側上下に各1つある例 (Plate 7 Figs A C) は1.6\%で, 背腹側上に各1つある のは(Plate 7 Figs D)少なく0.7\%にすぎない。VoigtDiskordanzの認められないのは(Plate 7 Figs E〜H, Plate 8 Figs A〜H)のは $85.2 \%$ ある。

横条線は明瞭な点で構成されており，放射状配列をす る。ケイ藻の種によってはケイ殸の外形に奇型の多いこ とがあるが，今回の試料では，外形に奇型は全くみられ ず，横条線が粗くなったり，1部欠除したりする奇型が (Plate 9 Figs A〜H) 横条線にのみみられたが，その 頻度は $1.8 \%$ で大きくない。

\section{3. 計測值}

ケイ殼長は $28 よ り 79 \mu \mathrm{m}$ ，幅12.5より $19.5 \mu \mathrm{m}$ である。 従来の記録はケイ款長 38 (Meister 1912)より $70 \mu \mathrm{m}\left(\mathrm{Kra}^{-}\right.$ 
mmer 1982), 幅14(Foged 1981)より $22 \mu \mathrm{m}$ (Krammer 1982）までで，ケイ款長においては従来の記録より，か なり小さいものも大型のものも見出すことができた。し かし，ケイ殼幅の下限では従来の記録より小型のものが あったが，上限は従来の記録内である。10 $\mathrm{\mu m}$ 間の横条 線密度 $(10 \mu \mathrm{m}$ 間の本数)はケイ殸の中央部背縁では6より 9本, 腹縁では7より12本で腹縁が少し密である。両端部 は背縁は9より14本, 腹縁は10より15本で, 先端部も腹 縁が背縁より多少密である。従来の記録は中央部で8 (Meister 1912)より12(Hustedt 1930)までで，下限は 今回の值の方が小さいが，上限は今回と同じである。両 端部は12(Cleve 1894)より17本(Hustedt 1930)までで, 下限が今回の值が小さく，上限は従来の範囲内である。 横条線を構成する点は $10 \mu \mathrm{m}$ 間に 12 より28ケであるが， 従来の記録は26(Patrick -Reimer 1975) より28(Patrick· Reimer 1975)で，下限は従来の值より下で上限は同じ である。

ケイ款長と幅の相関関係を図 2 に示す。相関係数 $\gamma=$ 0.695 で両者間に正の相関関係を認めることができる。 回帰式は $\mathrm{y}=0.103 \mathrm{x}+10.415$ である。

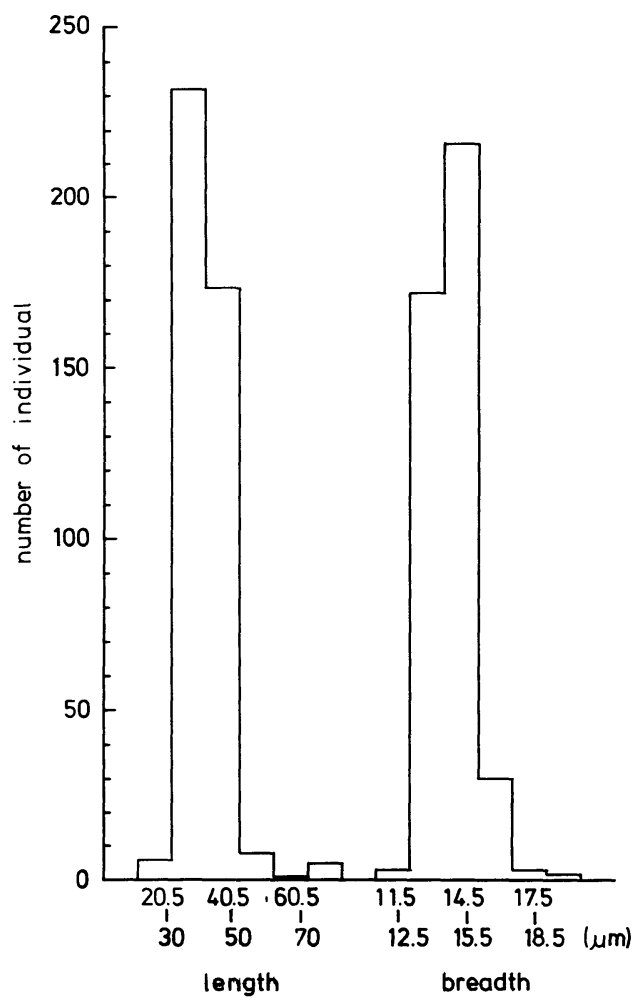

Fig. 1 Cymbella lata Grun. ケイ殼長と幅のヒストグラム

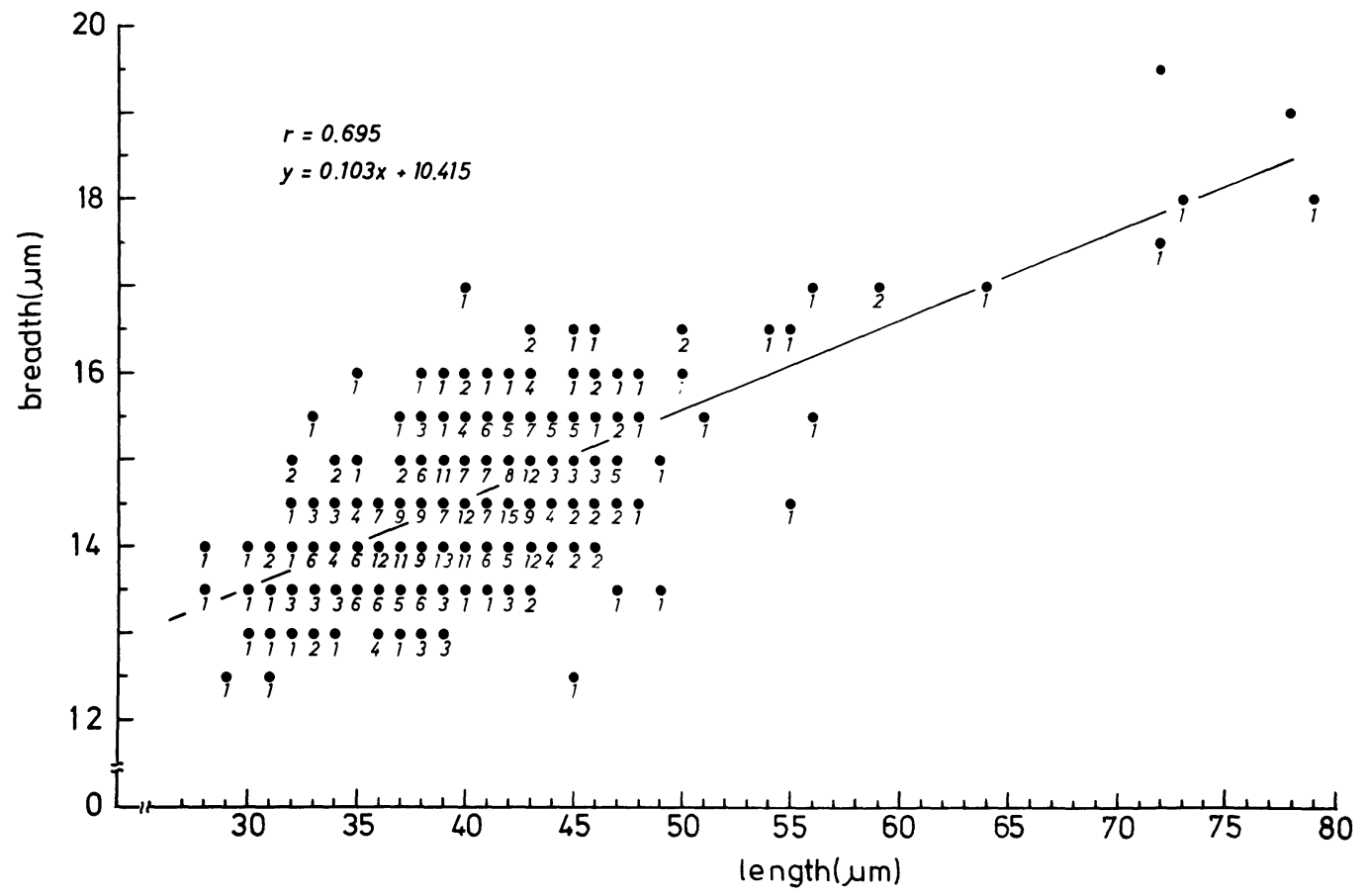

Fig.2 Cymbella lata Grun. ケイ凯長と幅の相関関係図 


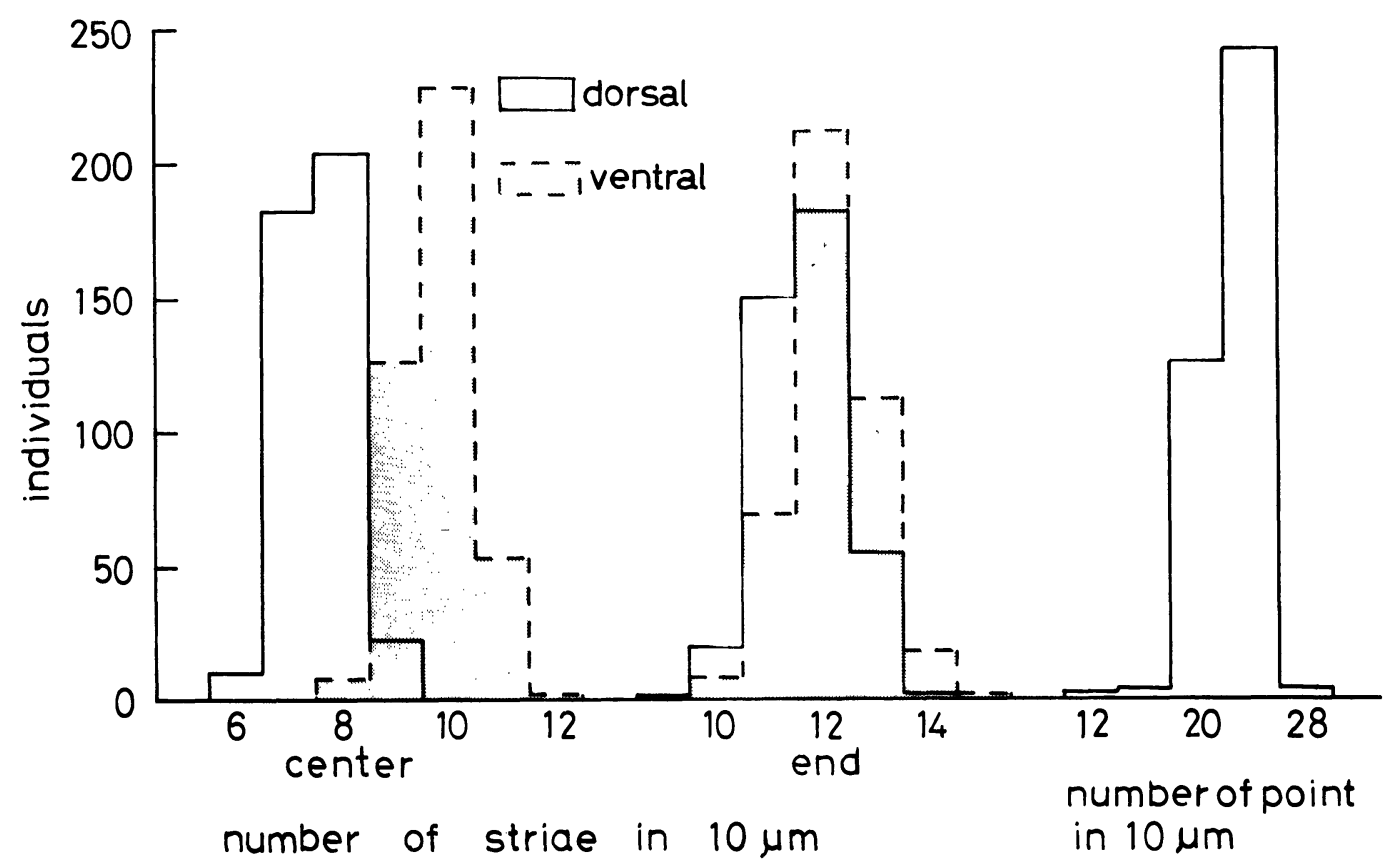

Fig.3 Cymbella lata Grun. 横条線密度のヒストグラム

Table1 Cymbella lata Grun. 諸形質の出現頻度

\begin{tabular}{|c|c|c|}
\hline \multicolumn{2}{|c|}{ 形 質 } & 頻度 (\%) \\
\hline 腹縁中央部 & $\begin{array}{l}\text { ほほ真直 } \\
\text { やや湾出 }\end{array}$ & $\begin{array}{l}63.8 \\
36.2\end{array}$ \\
\hline 軸域 & $\begin{array}{l}\text { やや狭い } \\
\text { 中位から幅広い }\end{array}$ & $\begin{array}{l}11.3 \\
88.7\end{array}$ \\
\hline 中心域 & $\begin{array}{l}\text { 大きくない } \\
\text { 大きい }\end{array}$ & $\begin{array}{l}16.9 \\
83.1\end{array}$ \\
\hline 中心域の大きさ & $\begin{array}{l}\text { 背腹ほほ同じ } \\
\text { 背側が腹側より大 } \\
\text { 背側が腹側より小 }\end{array}$ & $\begin{array}{l}67.4 \\
20.9 \\
11.7\end{array}$ \\
\hline Voigt-Diskordanz & $\begin{array}{l}\text { 背側上に } 1 \text { つあり } \\
\text { 背側下に } 1 \text { つあり } \\
\text { 背側上下に各 } 1 \text { つあり } \\
\text { 腹側上に } 1 \text { つあり } \\
\text { 腹側下に } 1 \text { つあり } \\
\text { 背, 腹側上に各 } 1 \text { つあり } \\
\text { ない }\end{array}$ & $\begin{array}{r}4.7 \\
3.8 \\
0.9 \\
3.1 \\
1.6 \\
0.7 \\
85.2\end{array}$ \\
\hline 奇型 & $\begin{array}{l}\text { 横条線にある } \\
\text { みられない }\end{array}$ & $\begin{array}{r}1.8 \\
98.2\end{array}$ \\
\hline
\end{tabular}

\section{4. 論議}

Plate 1上段に示すような腹縁の中央部がまっすぐな 個体は図に示すように一般に小型で，下段に示すように 腹縁の湾出する個体は大型で, Plate 1をみると両者は 別種であると考えたくなる。しかし, Plate 10に示すよ うに, 腹縁の湾出する個体 $\mathrm{AB}$ は CD と連続してゆき同 一のtaxonにすべきと考えるようになる。Plate $10 \mathrm{Fig}$. Eのように腹縁の湾出する個体にも小型のものがあり， 腹縁の湾出するものはすべて大型とはいえないことが判 明する。しかし，逆に大型の個体には腹縁中央部の真直 な個体は全くなく，腹縁中央部は必ず湾出している。以 上記したような形態を示す今回の資料はPlate 11より Plate 13に示すCymbella lata Grun. と同定すべきと 考えられる。ここに示す図で腹縁中央部が明らかに真直 に表現しているのはCleve-Euler 1953(本論文Plate 12 Figs. C·E), Patrick $\cdot$ Reimer 1975(本論文Plate 13 Fig. A), Wujeck $\cdot$ Rupp 1980 (同Fig. B), Krammer $\cdot$ LangeBertalot 1986(同Fig.F)で, Plate 11より13まで16の 本種の図や顕微鏡写真の中腹縁中央部が真直なのは4 で, その頻度は $25 \%$ で, 今回の資料の $64 \%$ と比較すると 大変小さい値である。Krammer·Lange-Bertalot 1986 Fig. 143:18(本論文Plate 13 Fig. G)のように背腹性 
の大変弱い個体は今回は検出することができなかった。

Cymbella lataの主なtaxaをPlate 14・15に示し, 主 要研究者の計測値をTable 4に示す。Cymbella late v. baicalensis Skv. et Mayer(Plate 14 Figs. A·B)は 腹縁が真直か少し湾入する形態で, 今回の試料と外形が 明らかに異なり，このtaxaの中に入れるべきか否かを 検討せねばならない。Var. minor Mölder(Plate 14 Fig. C) は小型 $(15 \sim 25 \mu \mathrm{m} \times 6 \sim 10 \mu \mathrm{m})$ である点で区別が 可能である。Var. nipponica Skv. (Plate 14 Figs D) は背縁が波打っている点で区別が可能である。var. nipponica Skv. (Plate 14 Figs E·F)はケイ殸幅が狭 い $(9 \sim 12 \mu \mathrm{m})$ 点で区別が可能である。このように検討す ると, 今回研究した個体群は基本種var. lateと同定すべ きである。

なお, Pantocsek(1901)がCymbella lotzyii Pantocs eckとしている原因の1つPantocsek 1901 Plate 1 Fig. 10(本論文Pl. 14 Fig. G) は今回研究した個体群の腹縁中 央部真直な個体群と区別が困難で, 他の1つFig.11(同P late $14 \mathrm{Fig.H}$ ) は腹縁の湾出する個体群で比較的小形 な個体群と区別が困難であるためV an Landingham (1969)の記しているようにCymbella lataのsynonymに すべきである。
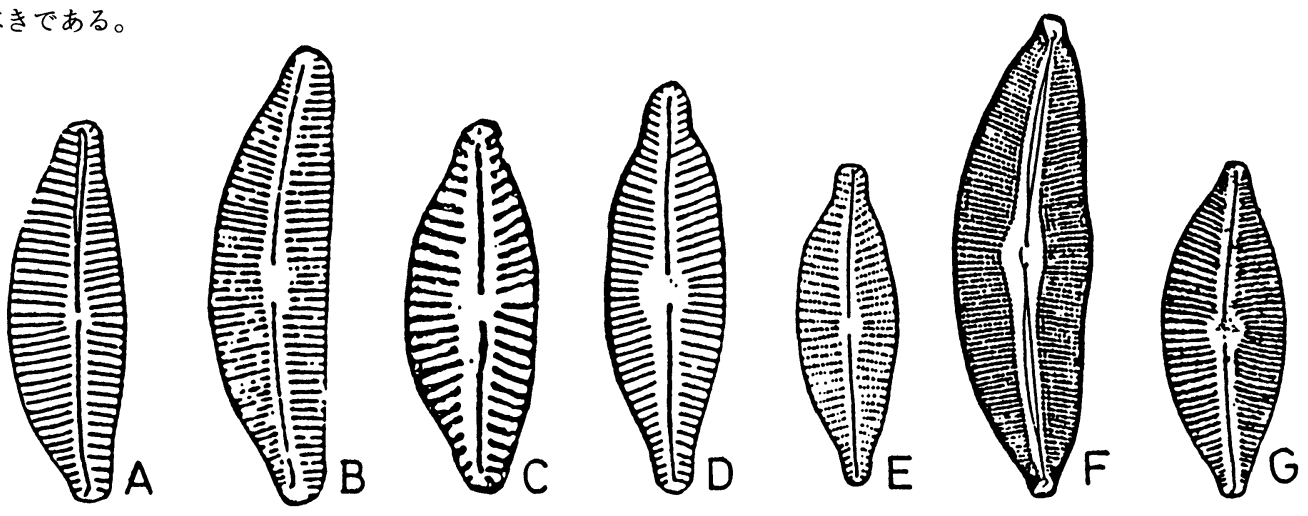

Table 2. Cymbella lata Grun.の主要taxaの検索表 I ケイ殸の背腹性がかなり強い I) 腹縁中央部の湾出が強い

II) 腹禄中央部が湾出しない var. nipponica Skv.1935 A .vvar. baicalensis Skv. et Mayer 1928 B

】ケイ殼の背腹性が弱い

I ) ケイ款の幅は狭い $(12 \mu \mathrm{m}$ 以下 $)$

（）ケイ殸は小型である(ケイ殼長 $15 〜 25 \mu \mathrm{m}$ )

(II) ケイ殼はそれ程小型でない(ケイ殼長 $27 \sim 37 \mu \mathrm{m})$

II) ケイ款幅はそれ程狭くない $(16 \mu \mathrm{m}$ 以上 $)$

（I）ケイ殸は大型で $(103 \times 30.5 \mu \mathrm{m})$ 横条線の点紋は粗 $(11 / 10 \mu \mathrm{m})$ .var. lata f. tumido-ventralis Manguin $1952 \mathrm{~F}$

（II）ケイ款はそれ程大型でなく $(40 ７ 0 \times 16 ２ 2)$ 横条線の点紋は密 $(26 \sim 28 / 10 \mu \mathrm{m})$ var. lata $G$ 
Table 3 Cymbella lata Grun. 測定值

\begin{tabular}{|c|c|c|c|c|}
\hline \multicolumn{2}{|c|}{ 研 究 者 (年度) } & $\begin{array}{l}\text { ケイ款長 } \\
(\mu \mathrm{m})\end{array}$ & $\begin{array}{c}\text { ケイ款幅 } \\
(\mu \mathrm{m})\end{array}$ & $10 \mu \mathrm{m}$ 間の横条線数 \\
\hline Cleve & $(1894)$ & $42-56$ & $16-18$ & $9(\mathrm{~m}) \quad 12(\mathrm{e})$ \\
\hline Meister & $(1912)$ & $38-60$ & $15-18$ & $8-9(\mathrm{~m})$ \\
\hline Hustedt & $(1930)$ & $40-60$ & $16-18$ & $9-12(\mathrm{~m}) \quad 17(\mathrm{e})$ \\
\hline Sabeline et al. & $(1951)$ & $40-60$ & $16-18$ & $9-12(\mathrm{~m}) \quad 17(\mathrm{e})$ \\
\hline Patrick \& Reimer & (1975) & $40-60$ & $16-19$ & $9-10(\mathrm{~m}) \quad 14-17(\mathrm{e}) 26-28(\mathrm{p})$ \\
\hline Wujeck \& Rupp & $(1980)$ & 42 & 16 & $10(\mathrm{~m}) 15(\mathrm{e})$ \\
\hline Foged & $(1981)$ & 41 & 14 & $11-12$ \\
\hline Germain & $(1981)$ & $40-60$ & $16-18$ & $10-12$ \\
\hline Krammer & $(1982)$ & $40-70$ & $16-22$ & $7-9(\mathrm{~m}) \quad 26-28(\mathrm{p})$ \\
\hline $\mathrm{Kramer} \cdot$ Lange-Berta & $(1986)$ & $40-70$ & $16-22$ & 8-12(m) $16-17(\mathrm{e}) \quad 26-28(\mathrm{p})$ \\
\hline 今回の試料 & & $28-79$ & $12.5-19.5$ & $\begin{array}{l}6-9(\mathrm{dm}) 7-12(\mathrm{vm}) 9-14(\mathrm{de}) \\
10-15(\mathrm{ve}) 12-18(\mathrm{p})\end{array}$ \\
\hline
\end{tabular}

Table 4 Cymbella lata Grun. 測定值

\begin{tabular}{|c|c|c|c|c|c|}
\hline \multirow{2}{*}{$\begin{array}{c}\text { 分 類 群 } \\
\text { C.l.f.tumidoventralis }\end{array}$} & \multicolumn{2}{|l|}{ 研究者（年度） } & \multirow{2}{*}{$\frac{\begin{array}{l}\text { ケイ殸長 } \\
(\mu \mathrm{m})\end{array}}{103}$} & \multirow{2}{*}{$\begin{array}{c}\begin{array}{c}\text { ケイ殼幅 } \\
(\mu \mathrm{m})\end{array} \\
30.5\end{array}$} & \multirow{2}{*}{$\begin{array}{l}10 \mu \mathrm{m} \text { 間の横条線数 } \\
7-8(\mathrm{~d}) 8-9(\mathrm{v}) 11(\mathrm{p})\end{array}$} \\
\hline & Manguin & $(1952)$ & & & \\
\hline \multirow[t]{2}{*}{ C.l.v.baicalensis } & Skvortzow et Mayer & (1928) & $35-45.9$ & $10.2-15$ & $9-12$ \\
\hline & Sabel ina et al. & $(1951)$ & $35-45.9$ & $10.2-15$ & $9-12$ \\
\hline C.l.v.minor & Sabel ina et al. & $(1951)$ & $15-25$ & $6-10$ & \\
\hline C.l.v. nipponica & Skvortzow & $(1935)$ & 39 & 12 & 10 \\
\hline C. l. v. sinica & Skvortzow & $(1935)$ & $27-37$ & $9-12$ & $10-12(d)$ \\
\hline C. lotzyii & Pantocsek & $(1901)$ & $39-42$ & $12-16$ & $8-12(\mathrm{~d}) \quad 10-13(\mathrm{v})$ \\
\hline 今 回 & の 試 料 & & $28-53.5$ & $12.5^{-17}$ & $\begin{array}{l}\text { 6-9(dm) } 7-12(\mathrm{vm}) 9-14(\mathrm{de}) \\
10-15(\mathrm{ve}) \quad 12-28(\mathrm{p})\end{array}$ \\
\hline
\end{tabular}




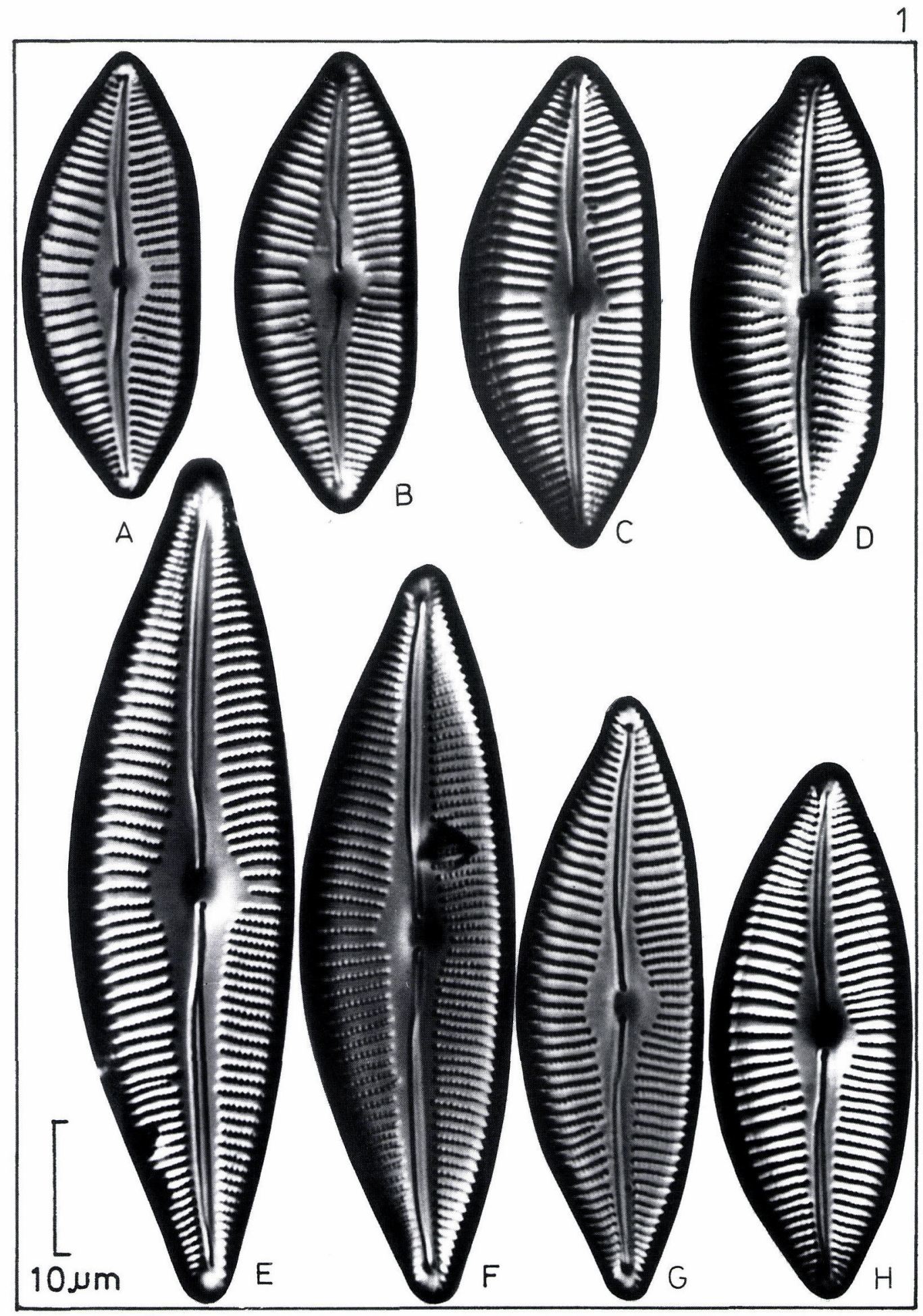

Cymbella lata Grun

$\mathrm{A}-\mathrm{D}$ ：腹縁中央部がほぼまっすぐ(11.3\%)

$\mathrm{E}-\mathrm{H}$ : " がやや湾出 $(36.2 \%)$ 


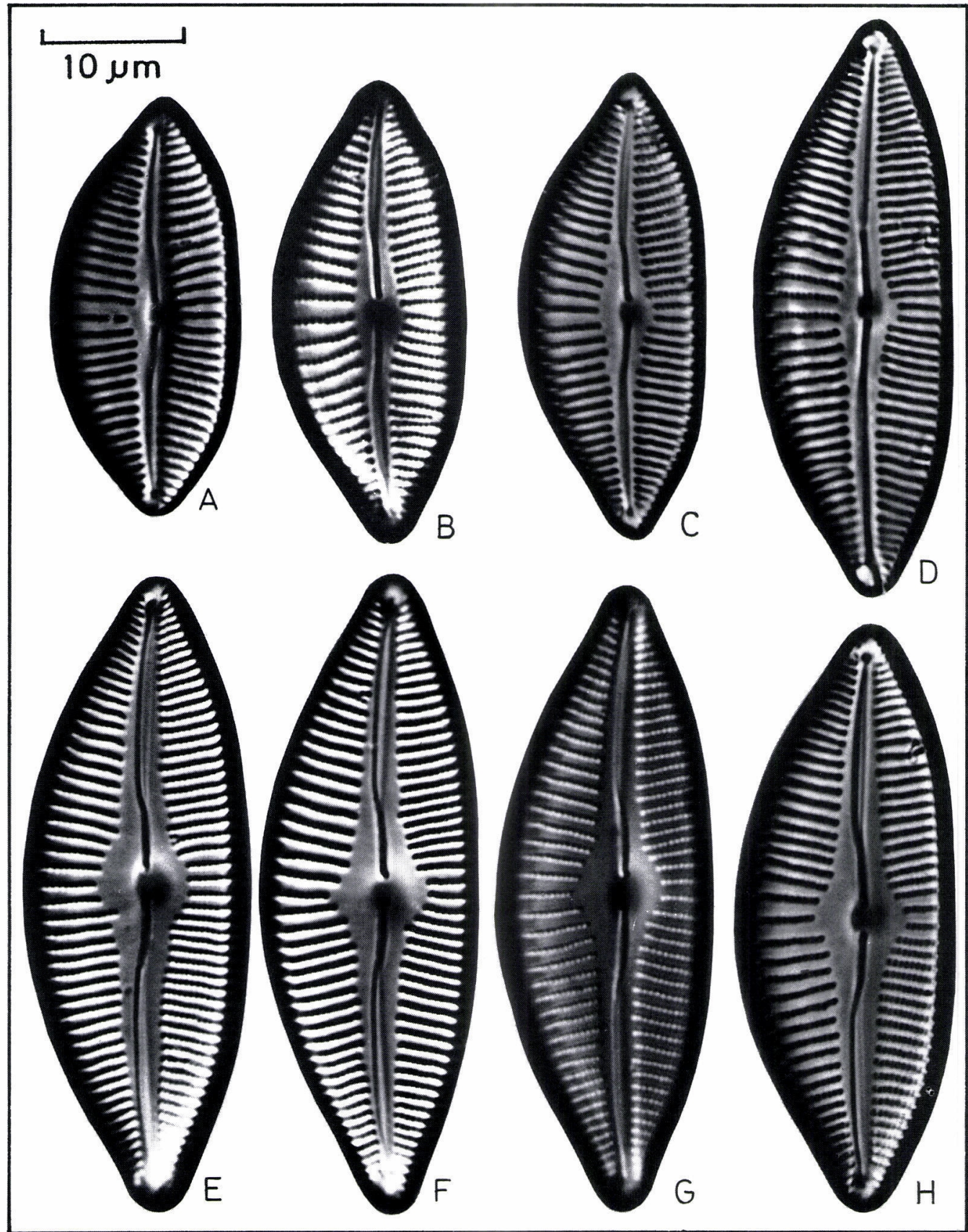

Cymbella lata Grun.

A-D：中心域は大きくない $(16.9 \%)$

$\mathrm{E}-\mathrm{H}$ ：" "は大きい(83.1\%) 


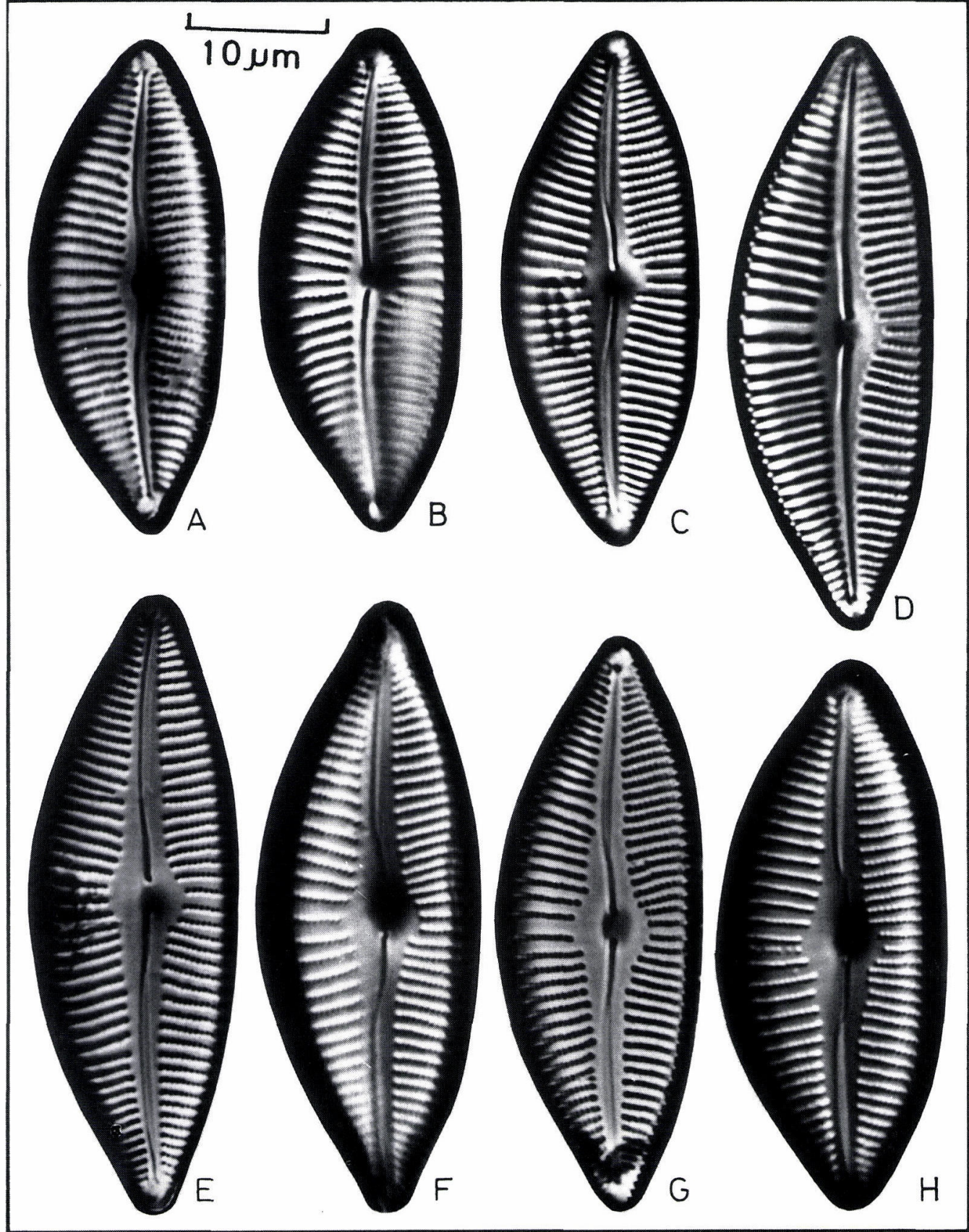

Cymbella lata Grun.

$\mathrm{A}-\mathrm{D}$ ：軸域はやや狭い $(11.3 \%)$

$\mathrm{E}-\mathrm{H}$ ：”は中位から幅広い $(88.7 \%)$ 